\title{
Picturing Liminal Spaces and Bodies: Rituals of Punishment and the Limits of Control at the Gallows Field
}

\section{Anuradha Gobin}

Volume 43, numéro 1, 2018

URI : https://id.erudit.org/iderudit/1050817ar

DOI : https://doi.org/10.7202/1050817ar

Aller au sommaire du numéro

\section{Éditeur(s)}

UAAC-AAUC (University Art Association of Canada | Association d'art des universités du Canada)

\section{ISSN}

0315-9906 (imprimé)

1918-4778 (numérique)

Découvrir la revue

Citer cet article

Gobin, A. (2018). Picturing Liminal Spaces and Bodies: Rituals of Punishment and the Limits of Control at the Gallows Field. RACAR : Revue d'art canadienne / Canadian Art Review, 43(1), 7-24. https://doi.org/10.7202/1050817ar
Résumé de l'article

Cet article se penche sur un ensemble d'images de corps châtiés dans le paysage hollandais afin d'explorer le rôle de l'espace dans les conceptions de criminalité et d'identité au cours du XVII ${ }^{\mathrm{e}}$ siècle. À cette époque, les cadavres de certains criminels, exécutés pour des crimes exceptionnellement graves, étaient déplacés sur les sites de pendaison, situés au-delà des murs de la ville. Étant donné la présence de restes humains en décomposition, il est frappant que la périphérie des villes attirât les membres du public en grand nombre. Les gens se réunissaient pour voir cette manifestation de pouvoir autoritaire sur les actes criminels, mais aussi pour s'amuser et profiter d'activités de loisir avec leur famille, leurs amis et des étrangers. Cet article examine les représentations de gibets afin d'interroger comment les activités non autorisées se déroulant sur ces sites pouvaient négocier ou transformer l'identité civique dans la République hollandaise.
Tous droits réservés (C) UAAC-AAUC (University Art Association of Canada | Association d'art des universités du Canada), 2018
Ce document est protégé par la loi sur le droit d'auteur. L'utilisation des services d'Érudit (y compris la reproduction) est assujettie à sa politique d'utilisation que vous pouvez consulter en ligne.

https://apropos.erudit.org/fr/usagers/politique-dutilisation/ 


\section{Picturing Liminal Spaces and Bodies: Rituals of Punishment and the Limits of Control at the Gallows Field}

Anuradha Gobin

\begin{abstract}
Cet article se penche sur un ensemble d'images de corps châtiés dans le paysage hollandais afin d'explorer le rôle de l'espace dans les conceptions de criminalité et d'identité au cours du $\mathrm{xvII}^{\mathrm{e}}$ siècle. À cette époque, les cadavres de certains criminels, exécutés pour des crimes exceptionnellement graves, étaient déplacés sur les sites de pendaison, situés au-delà des murs de la ville. Étant donné la présence de restes humains en décomposition, il est frappant que la périphérie des villes attirât les membres du public en grand nombre. Les gens se réunissaient pour voir cette manifestation de pouvoir autoritaire sur les actes criminels, mais aussi pour s'amuser et profiter d'activités de loisir avec leur famille, leurs amis et des étrangers. Cet article examine les représentations de gibets afin d'interroger comment les activités non autorisées se déroulant sur ces sites pouvaient négocier ou transformer l'identité civique dans la République hollandaise.
\end{abstract}

Anuradha Gobin is Assistant Professor of Art History in the Department of Art at the University of Calgary. -anuradha.gobin@ucalgary.ca
Hendrick Avercamp's painting Riverscape at Kampen | fig. 1 | highlights an array of typical summer activities occurring along a river. In the foreground of the composition, two male figures seated at the water's edge direct their attention to a freshly caught fish being detached from the line of a man wearing a hat. His companion looks on and awaits a tug on his line, which he secures by sitting on the handle of the rod. A third man, with his fishing rod and basket strung on his shoulder, looks on from behind. On the other side of the seated men, a dog raises its head to acknowledge the retrieval of the fish. Two small boats float by on the expanse of water, each occupied by a pair of figures who cast fishing lines into the water. Swans and ducks float calmly past, while two cows enjoy the grass and water. To the left of the composition, near the edge of the image, a solitary man repairs fishing nets strung between poles. On the opposite side, two women with a young child are seated on the grass, while their male companion observes a nearby hunter pointing his gun at a bird in mid-flight. Behind them, a woman and young child walk along a road with a horse-drawn carriage moving in the direction of a city outlined in the distance. In the background of the image, the faint outline of buildings and a church tower may be discerned.

Remarkably, none of the fifteen figures gathered along the river appear to notice the two cadavers on the gallows near the water's edge. These hanging bodies are positioned so that they give the impression of overlooking the idyllic summer activities unfolding before them. In the lower left foreground of the composition, positioned near the edge, lies the skull of a horse. Like the hanging bodies, this detail seems to go unnoticed by any of the figures in the landscape scene. Its inclusion, however, introduces a temporal dimension to the image, as it foreshadows the future decomposition of the hanging cadavers.

Despite the apparent indifference of the figures in Avercamp's composition, civic authorities in the seventeenth-century Dutch Republic intended the display of executed bodies on the gallows to be a remarkable feature of the landscape. They were meant to deter illegal actions by vividly reminding potential wrongdoers of the grisly consequences of crime. This anticipated reaction is rendered quite strikingly in a drawing produced by Anthonie van Borssom in 1664, | fig. 2 | in which criminal bodies are represented in varying states of decomposition. Five standing figures direct their attention to the exhibited bodies and appear to be contemplating the fate of the convicts, thereby internalising the moral messages the spectacle of their corpses was intended to convey. 
1. See Mitchell B. Merback, The Thief, the Cross and the Wheel: Pain and the Spectacle of Punishment in Medieval and Renaissance Europe (Chicago: The University of Chicago Press 1999), 48-100.

2. Catherine Levesque, "Truth in Painting-Comedic Resolution in Bruegel's Landscape with the Magpie on the Gallows," in Parody and Festivity in Early Modern Art: Essays on Comedy as Social Vision, ed. David R. Smith (Farnham and Burlington: Routledge, 2012), 68.

3. W.J.T. Mitchell, What Do Pictures Want? The Lives and Loves of Images (Chicago: The University of Chicago Press, 2005), 2-11.
The images by Avercamp and van Borssom provide two contrasting examples of behaviour at the gallows and in proximity to punished bodies. Neither artist was unique in producing images featuring occupied gallows, which were depicted in different media and for a variety of contexts. Indeed, such images are part of a long and well-established visual tradition that predates both compositions. Gallows appeared most commonly in medieval and early modern religious scenes depicting Calvary and Christ's crucifixion. These devotional images were meant to provoke contemplation of the earthly suffering of Christ, while also prompting reflection on the inevitability of death and the afterlife. ${ }^{1}$ The gallows were also featured in scenes of country life and landscape prints. As Catherine Levesque has noted, their inclusion in such images was intended as a reminder of mortality. ${ }^{2}$ While the motif of the gallows has carried memento mori connotations since at least the early medieval period, its presence in scenes of seventeenth-century life suggests that it also came to be linked to civic authority. Criminals punished by city officials were displayed on gallows with the explicit intention of deterring future offenders through visualizing the consequences of crime. While the suppression of illicit activities may have been the official intention behind the use of the gallows in the Dutch Republic, the production of images like Avercamp's, in which the reprimanded bodies generate no interest, suggests alternative possibilities for the site. The range of images of the gallows produced suggests that they were material agents of the ideas and values then circulating in society associated with punished, criminal bodies. Instead of only functioning as a reminder of death or a deterrent to crime, the gallows may have also served as a visual trope that, at times, exceeded the parameters of control over unlawful behaviour. Through close readings of images of the gallows, in conjunction with contemporary accounts, this article seeks to explore the importance of this site in mediating certain social hierarchies. The importance of visual culture to the creation of a space in which anxieties could be tested and debated without direct threat to established power structures will also be demonstrated. As scholars like W. J. T. Mitchell have noted, images do not function merely as "imitations of life"-they also have the ability to take on "lives of their own," shaping the way people perceive the world around them. ${ }^{3}$ Building on this conception of the vitality of images, the present article will explore the potential impact of representations of the gallows on the behaviour and beliefs of those who interacted with these images. Given the lack of historical information regarding how viewers reacted to or perceived the specific images under consideration, some transhistorical psychological projection will be employed in the following analysis. This is done, however, with due consideration to established historical behaviours, and with the intention of expanding the potential connotations and associations of the gallows and its prominence in visual culture.

\section{Official Treatment of Executed Bodies}

Jacob Bicker Raye recorded his impressions of a public execution he witnessed on January 11,1766 . From his diary entry, we understand that executions in the Dutch Republic were highly ritualized and followed carefully formulated ceremonial procedures. Raye refers to these as "ontsaggelijke plegtigheeden," or 


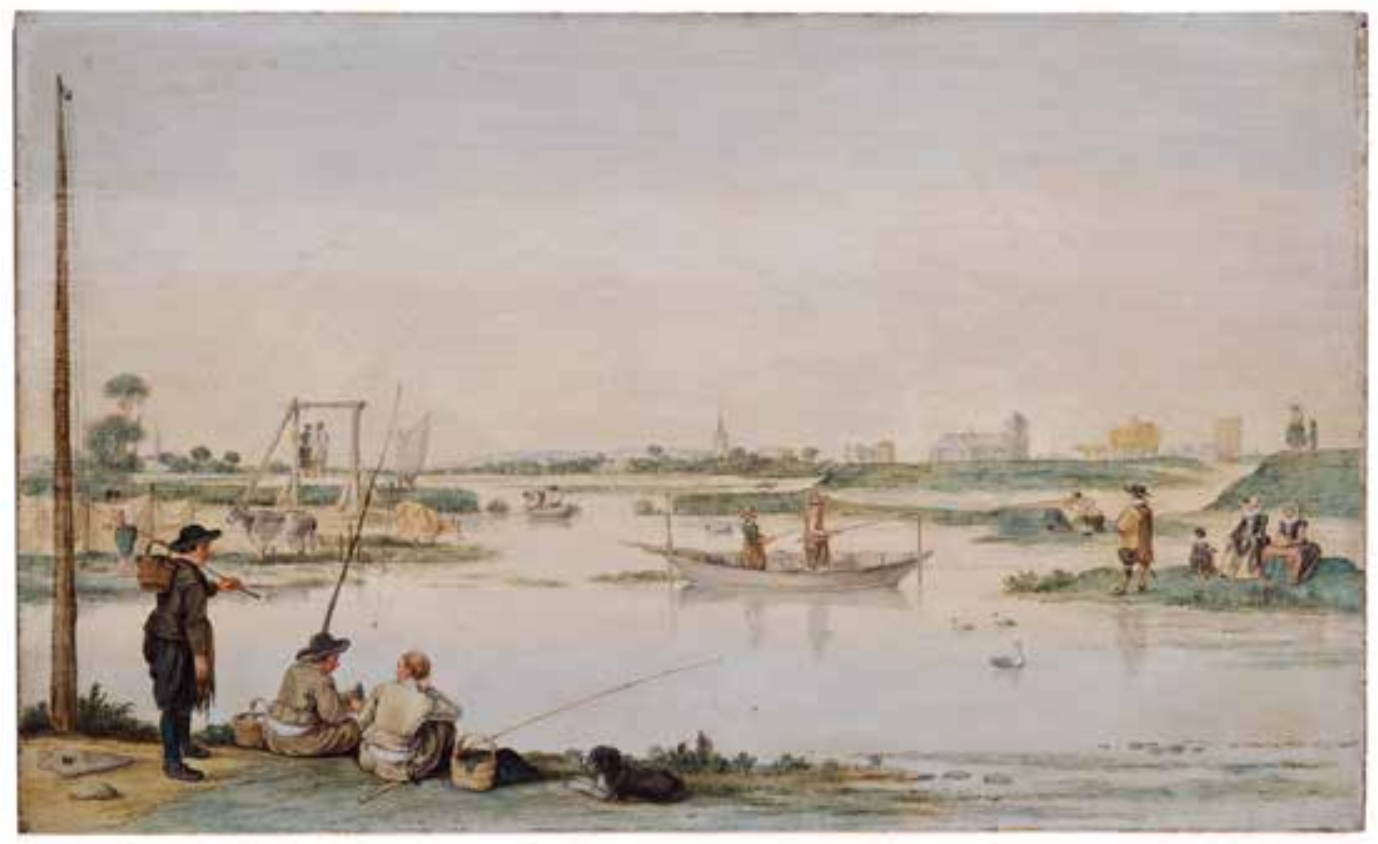

Figure 1. Hendrick Avercamp,

Riverscape at Kampen, c. 1620-25.

Panel, $24 \times 39.2 \mathrm{~cm}$. Fondation

Custodia, Frits Lugt Collection, Paris.

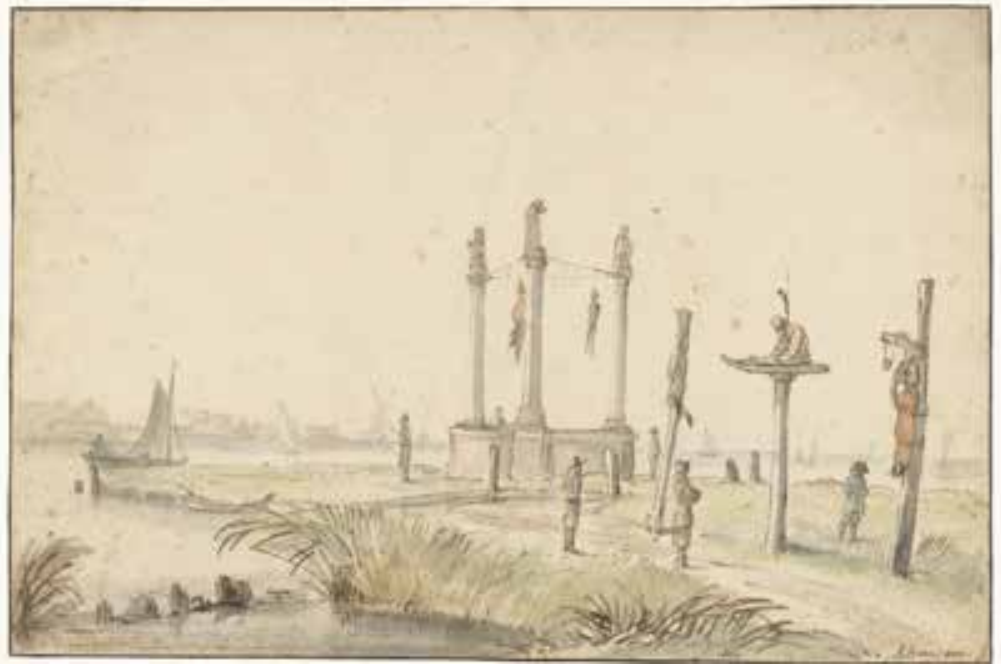

Figure 2. Anthonie van Borssom,

View of the Gallows Field at Volewijk

Outside of Amsterdam, 1664. Pen

and brown ink, watercolour on

paper, $20.5 \times 31.8 \mathrm{~cm}$. Rijksmuseum,

Amsterdam. 
4. Frederik Beijerinck and M.G de Boer, eds., Het Dagboekvan Jacob Bicker Raye, 1732-1772: Naar Het OorspronkelijkDagboekMedegedeeld (Amsterdam: H.J. Paris, 1935), 297.

5. Pieter Spierenburg, The Spectacle of Suffering: Executions and the EvoIution of Repression: From a Preindustria Metropolis to the European Experience

(Cambridge: Cambridge Univeristy Press, 1984), 58.

6. Florike Egmond, Underworlds: Organized Crime in the Netherlands 1650-1800 (Cambridge: Polity Press, 1993), 29-30.

7. The urban location of the gallows fields in the province of Holland was near Amsterdam, Haarlem, Alkmaar, Hoorn, Enkhuizen, Leiden, the Hague (two), Delft, Gouda, Woerden, and Dordrecht. See Herman Diederiks, "Urban and Rural Criminal Justice and Criminality in the Netherlands since the Middle Ages: Some Observations," in The Civilization of Crime: Violence in Town and Country since the Middle Ages, eds. Eric A. Johnson and Eric $\mathrm{H}$. Monkkonen (Urbana and Chicago: University of Illinios Press, 1996), 153-64.

8. In Amsterdam, some corpses were also occasionally hung outside the city gates. See H.C. Jelgersma, Galgebergen en galgevelden in West-en Midden Nederland (Zutphen: Walburg Pers 1978), 41. awesome ceremonies, that included not only the actual moment of execution, but also processions preceding the exhibition of certain bodies after death. ${ }^{4}$ These carefully choreographed spectacles were intended to project the impression that civic officials were in control of city boundaries, as well as the activities occurring within their borders. Public executions typically took place on a structure built specifically for the occasion outside the Town Hall. According to the instructions of some official sentences, the bodies of certain criminals were then moved to the gallows for further display. While not all felons condemned to death were sentenced to have their bodies decompose on the gallows, approximately half were given this additional penalty. For example, 214 of the 390 criminals sentenced to death in Amsterdam between the years 1650 and 1750 were also subject to this punishment. ${ }^{5}$ The lawbreakers strung on the gallows were considered the worst and most frequent offenders. These included those who committed murders or violent robberies, as well as those who combined crimes against the body, such as assault, with crimes against property, such as robbery. It was also the penalty for those whose previous offences and convictions had reached a critical point. ${ }^{6}$

In the province of Holland, twelve gallows fields were located just outside areas of urban settlement. ${ }^{7}$ Executed criminals would be transported there in what was another component of the formalized rituals that accompanied public punishments. In Amsterdam, for example, the main gallows field-the Volewijk-was located at the northern border of the city, along the central shipping route. ${ }^{8}$ Following execution, corpses would be collected from outside the Town Hall and either placed on a wagon, which was pulled by a horse, or physically dragged through the streets by the executioner. An anonymous, seventeenth-century print visualizes the manner in which these punished bodies were transported during the procession to the gallows. | fig. 3| After being dragged or carted away from the Town Hall, the corpse would arrive at the water's edge. Once there, it would be taken to the Volewijk via boat, where it would be placed on the gallows located at this marker of the city.

A crowd of onlookers often accompanied the transportation of the dead body from the Town Hall to the Volewijk. The anonymous print indicates this through the inclusion of a number of boats, represented in the foreground of the composition, some of which are filled with the passengers who made the journey with the executioner. In one of the boats, at the centre of the composition, lies the unclothed, lower torso of an executed felon. While it is possible to see that the cadaver's legs have been bound, its upper torso is cut off by the edge of the image. Two men, likely the executioner and his assistant, are in the process of dragging this body from the boat. In the background of the image are examples of the possibilities that await the newly arrived body. The artist has included a number of other cadavers already exhibited in a variety of positions. Some have been strung from the gallows, others are tied on top of a wheel, while the remaining criminals have had their heads fitted into $\mathrm{V}$-shaped poles, with their bodies hanging limply below. To the left of the composition, a group of well-dressed figures appears to have just disembarked from the empty boats behind them. These men are shown observing the condemned bodies already on view and serve as witnesses to the process unfolding as the corpse is removed from the boat by the executioner. The artist has 
Figure 3. Anonymous, The Bodies of the Anabaptists on the Gallows, c. 1650-1699. Engraving and Etching, $12.0 \times 13.9 \mathrm{~cm}$. Rijksmuseum, Amsterdam.
9. Stuart Hall, "Introduction," in Representation: Cultural Representations and Signifying Practices, ed. Stuart Hall (London: Sage Publications, 1997), 9-10.

10. Executioners were paid three guilders extra to hang objects symbolizing stolen property above a convict's head. Spierenburg, The Spectacle of Suffering, 212.

11. Richard Rawlinson, "Account of a Journey to Paris and the Low Countries" (unpublished manuscript), Oxford, Bodleian Library, MS. Rawlinson D. 1191.

12. For a list of charges by the provincial executioner for various actions performed on the dead criminal body, see Spierenburg, The Spectacle of Suffering, 212-13.

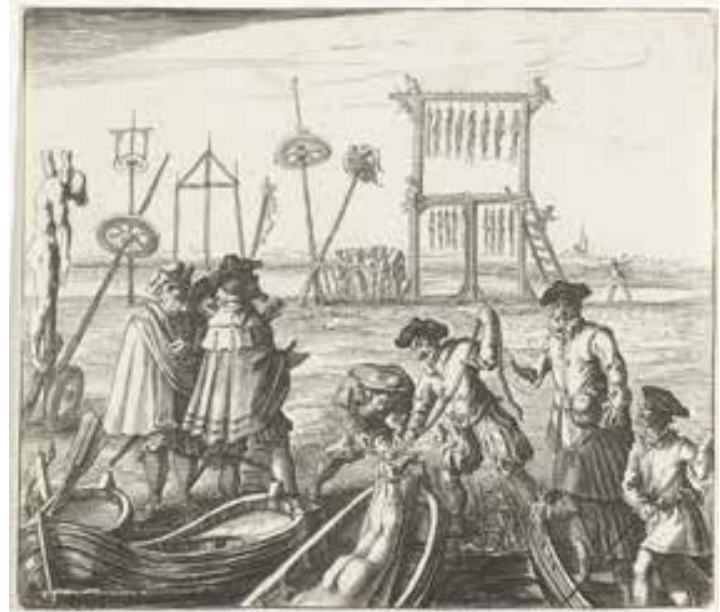

even included an outline of the city in the background of the composition, and a church spire and buildings are discernible on the horizon. While images like this cannot be taken as exact recordings of what occurred at the Volewijk, they do corroborate written accounts, such as Raye's, regarding the spectacular and public nature of the events that transpired there. Images like this may have been intended to provide an account of what occurred to punished cadavers after they left the Town Hall for those who did not travel to the Volewijk with the executioner. However, this meaning was not necessarily stable. As Stuart Hall has noted, intended meanings do not always survive the passage through representation intact. Meaning changes depending on context, usage, and circumstance, and is, therefore, in constant negotiation. ${ }^{9}$ While images of punished bodies displayed at the gallows may have been intended to signify control, this meaning had the potential to be manipulated or misconstrued by viewers.

Officials paid attention to how bodies were treated after death in an effort to ensure the maximum legibility of forbidden actions. For example, objects referencing either the weapon used in a murder or a stolen item would be hung with some bodies, for days or even weeks, as a means of emphasizing the nature of the crime. ${ }^{10}$ The effectiveness of this practice is made evident in a note by Richard Rawlinson, a British lawyer and antiquary, who visited the gallows field in Amsterdam on September 20, 1719. According to Rawlinson, there were several executed criminal bodies, and "[some] on the wheels had several pistols over their heads to denote that they were assassins." ${ }^{11}$ The inclusion of the weapons hanging overhead made the nature of the crime being punished apparent to even a foreigner. Beyond the exhibition of weapons, executioners were also paid additional fees for a variety of actions to be performed after death. Some of the officially recorded requests made of executioners include cutting off various body parts, placing severed parts of the body on the cadaver's trunk, drowning the corpse, and scorching its face. For example, the executioner would have been paid three guilders extra to drag a body to the Volewijk, seven if a carriage was used, six to hang it from the gallows, three to hang a weapon above the convict's head, and twelve for ropes and cords to support the body. ${ }^{12}$ 
Figure 4. Simon Fokke, Harnessess used to hang up criminals broken on the wheel, 1764 . Drawing. Stadsarchief Amsterdam.
13. Jonathan Sawday, "Self and Selfhood in the Seveenteenth Century," in Rewriting the Self: Histories from the Renaissance to the Present, ed. Roy Porter (London and New York: Routledge, 1997), 31.

14. Angela Vanhaelen, Comic Print and Theatre in Early Modern Amsterdam: Gender, Childhood and the City (Aldershot, UK, and Burlington, VT Ashgate Publishing Company, 2003), 152.

15. Fr de Witt Huberts, De Beul En Z'n Werk (Amsterdam: Andries Blitz, 1937), 53.

16. Spierenburg, The Spectacle of Suffering, 57-58.

17. William Brereton and Edward Hawkins, Travels in Holland, the United Provinces, England, Scotland, and Ireland, 1634-1635 (London: Printed for the Chetham Society, 1844), 49 18. Ibid.
In certain cases-when a crime was considered to be particularly harmful to the civic good, and therefore in need of severe punishment-special mechanisms were constructed to impress this fact upon the public. Simon Fokke produced a series of images recording the harnesses that were made to contain the bodies of a group of mutinous sailors. Dutch prosperity was largely derived from overseas expansion and trade, so the need to control the behaviour of sailors was imperative to the continuation of economic success. To send a message that mutiny would not be tolerated, the sailors were sentenced to be broken on the wheel and their bodies placed in specially constructed harnesses. Fokke's images depict the harnesses from varying angles and demonstrate the intricacy of planning involved in the construction of these contraptions. | fig. 4 | Based on their elaborate nature, it can be surmised that their production costs would have been sizable. Such expense, coupled with the added payment made to the executioner for any additional actions performed on the dead bodies, is indicative of the level of symbolic significance attached to how criminal corpses were handled. By including special instructions for the transportation and gibbeting of bodies in their official sentences, judicial authorities were actively conveying messages to those who would view and come into contact with these bodies.

Anthonie van Borssom's image View of the Gallows Field at Volewijk Outside of Amsterdam visualizes another type of activity that could occur at the gallows following the spectacle of transfer from the Town Hall. | fig. 2 | Like the anonymous print discussed above, this drawing highlights the physical division of the gallows field from the urban centre through its separation by water and the inclusion of the city's outline in the background of the image. Two boats are also shown at the edge of the water, indicating the method of transport that would have been required to arrive there. As noted earlier, the figures in van Borssom's drawing have travelled to the gallows and are depicted focusing their attention on the punished bodies. Quiet, calm, and solitary self-examination was an important component of Protestant teaching, and van Borssom's image visualizes this process in the observing men. ${ }^{13}$ At the right of the composition, a body is secured to a stake with an axe suspended above; this was an object associated with the crime. As Rawlinson's account makes clear, contemporary viewers would have understood the meaning of these suspended objects. Similarly, the figures pictured in van Borssom's image are depicted contemplating the cast-out criminals. It may be surmised that this contemplative act was part of a process of internalizing the laws governing a cohesive community. Furthermore, van Borssom's image may have elicited the same pensive turn inwards in the viewer of the drawing, who considers the depicted spectators scrutinizing the corpses. Through representation, the act of reflecting upon the fate of wrongdoers at the site of the gallows may have been extended to viewers of this image.

Images like van Borssom's and the anonymous print not only commemorated what occurred to some bodies following public execution, they also visually differentiated the spectators from those being punished. $\mid$ figs. 2, 3| The movement and accompanying formalized procession of the criminal corpse to a location outside the city limits can be viewed as a symbolic cleansing of the unacceptable transgressions committed by the offender. The process 
of expelling the body of the wrongdoer from the city, and the subsequent images that recorded such events, were important tools in establishing cultural cohesion in the community. As Angela Vanhaelen has argued, the repetition and ritual of expelling criminal bodies from the city allowed civic officials to "divide a purified interior from a polluted exterior, and to separate bodies within the walls from bodies arrayed on the outside." 14 Images of these rituals and the place of symbolic and physical expulsion thus solidified this demarcation beyond the temporal limits of the ontsaggelijke plegtigheeden and the eventual decomposition of the displayed bodies.

The decision to expose an executed cadaver on the gallows was thus intended to ensure that the repercussions of unlawful activity would be made evident to the maximum number of viewers. The careful management of the gallows and the bodies exhibited there-as evidenced, not only by the accompanying rituals, but also by the expenses incurred by officials-illustrates the importance of this site to the projection of power and control. The gallows as a marker of law is reinforced by reports that soldiers were required to salute them when they passed by. ${ }^{15}$ Additionally, during periods of war, a city's gallows were often a target for opposing forces as a symbolic destruction of the city's authority. ${ }^{16}$ The hanging bodies symbolically asserted that criminal and deviant behaviour would not be tolerated within the confines of the city under the jurisdiction of civic officials.

\section{Ambushed Landscapes}

Upon approaching the town of Haarlem during his tour of the United Provinces in 1634, the English traveller Sir William Brereton noted in his diary the presence of gallows publicly displaying the bodies of executed convicts. According to Brereton,

Here before we came to the town we saw a dainty gallows: three pillars of brick, iron bars overcross, whereon hang two men in chains, all flesh consumed. A woman executed stands here fixed to a post: she suffered for murdering her own child. She was put to a most cruel death upon a wheel. Another man's proportion [body] stands here, latterly erected and fastened to a new post. ${ }^{17}$

Brereton was no doubt describing the gallows recorded some years earlier by the artist Esaias van de Velde, who frequently painted landscape scenes around the town of Haarlem. | fig. 5 | Van de Velde's composition and

Figure 5. Esaias van de Velde, Landscape with Gallows, 1619. Oil on Panel, $13.5 \times 27 \mathrm{~cm}$. Gothenburg Museum of Art, Sweden.

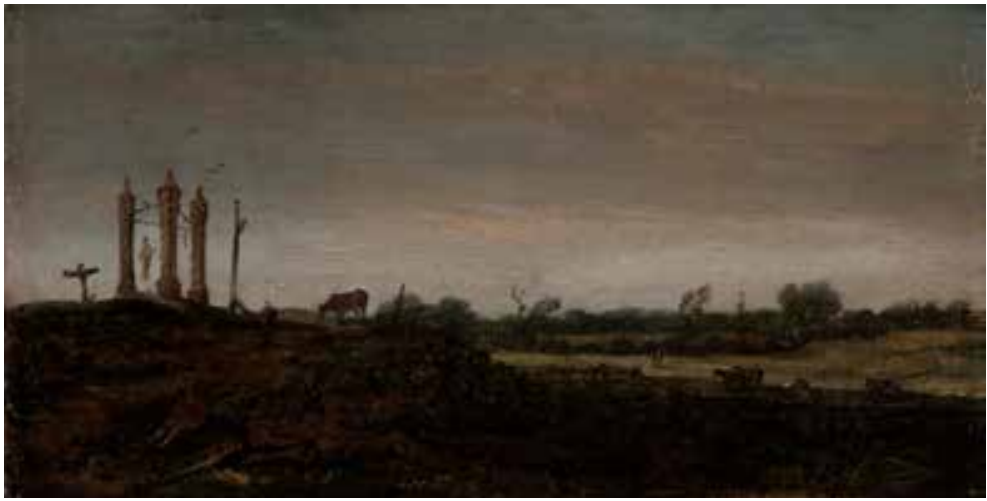


Brereton's diary entry provide further evidence of the encounter with damned bodies that people would have experienced in daily life. Van de Velde's image Landscape with Gallows includes the decomposing body of a criminal placed on an iron bar supported by three brick pillars. A man, perhaps a weary traveller, is depicted seated in the foreground of the composition with his back turned to the gallows. He appears relaxed and undisturbed by the scene behind him, and does not appear to register the corpse blowing in the wind. Similarly, Brereton quickly noted in his diary the presence of the decomposing bodies on the "dainty gallows" outside the town of Haarlem, but he does not include an emotional response to the sight. Once the brick structure that held the offending corpses is noted, he shifts his focus to describing the economic history and governance of the city. ${ }^{18}$

Brereton's lack of overt emotional response or sustained discussion of the displayed bodies recalls the actions of the figures in Avercamp's Riverscape at Kampen. | fig. 1 | Gallows were to be found in many cities and may have therefore become, for travellers like Brereton, a common feature of the landscape. Their inclusion in a range of visual culture may have also worked to desensitize others to their presence. This familiarity with decomposing human remains in public spaces would have been critical to mediating anxieties surrounding death, criminality, and the body. Through a process of normalizing the gallows as an intrinsic component of the landscape, such images helped to promote a level of familiarity with the decomposing corpse. While anxieties over the power and contaminating effects of the criminal corpse were not completely erased in practice, images of the rotting and broken body provided an opportunity for viewers to destabilize the officially sanctioned messages these images were intended to convey. As established above, official representations of the gallows field were important tools in the projection of authority and order. However, certain types of images held the potential for generating subversive ideas regarding the ability of officials to ensure the safety of the community from crime and illicit activity. This is notably evident in situations requiring travel between cities or towns.

Travel throughout early modern Europe was often difficult and potentially dangerous, as robbery by gangs of bandits was a real possibility. Levels of crime directed at travellers varied depending on location and other factors, such as war and economic instability. Generally speaking, towns in Holland were well governed. They had prosecutors, a chief constable, deputies, assistants, and a team of night watchmen tasked with crime prevention and detection. For example, until the end of the eighteenth century, the city gates of Amsterdam were locked at night and iron barriers lowered into the canals, thus preventing unauthorized access by either land or water. ${ }^{19}$ In spite of these precautions, concern over certain types of illegal activity remained a reality for travellers. This was markedly so in the Dutch countryside, where the power and influence of authorities was less strong. Evidence of concern over safety can be found in the growing popularity of images that record instances of criminal behaviour. Representations of banditry and ambush, produced for sale in the open market, became an increasingly popular subject during the seventeenth century. 
19. Florike Egmond, "Between Town and Countryside: Organized Crime in the Dutch Republic," in The Civilization of Crime, 139-140.

20. The original text reads: Annua rure suo transegit gaudia civis, / Cumque suis hilaris hinc petitecce domum./ Clanculum at occurrit saturis gens saeva latronum/Laetitiamque omnem barbara turba rapit./Fortunae hic lusus, rerumque estscaena volantum:/Excipit adversus fausta repentedolor.

21. For a discussion of this visual formula, see M. P. van Maarseveen, "Rustende Soldaten en Overvallen op Reizigers en Konvooien," in Beelden van een Strijd. Oorlogen Kunst voór de Vrede van Munster 1621-1648, eds. M.P. van Maarseveen, J.W.L. Hilkhuijsen, and J. Dane (Zwolle: Waanders, 1998), 134-147

22. Christopher P. Heuer, "Entropic Segers," Art History 35, 5 (November 2012): 935
One such image, a print by Jan van de Velde II titled Ambush of a Wagon, | fig. 6 | pictures an attack occurring at the boundary between the city and country. A cluster of structures, including a church, can be discerned through the trees. Groups of people are depicted gathered in front of these buildings, completely oblivious to the robbery taking place just beyond the city limits. In the foreground of the composition, the carriage driver is shown raising a dagger toward the approaching assailant in an attempt to defend the occupants and goods in the wagon. The woman in the wagon is in a state of alarm, as two robbers approach her from their place of cover in the forest. The Latin text included below the image tells the story of a merry group of travellers making their way home, while reminiscing about their visit to the countryside. Their enjoyment, however, comes to a sudden end as a "savage" group of outlaws attack their wagon. The text states:

In his own countryside the citizen has completed his annual joys, and with his family happily, look, makes his way home from here. But secretly a savage race of thieves runs up to the replete people and all their joy the barbarous mob snatches away.

This is fortune's game, and a scene of fleeting things:

adverse pain suddenly succeeds prosperity. ${ }^{\circ}$

Through both the visual and textual elements, the viewer is made aware of the potential harm that can occur to travellers in the liminal spaces beyond city walls and the reach of law. The accompanying text also directs attention to the fleeting characteristic of fortune and the cyclical nature of prosperity and pain.

Scenes of ambush and robbery were not only depicted in prints but also in paintings. Images of travellers being attacked by bandits developed into an established visual formula in Netherlandish painting in particular. ${ }^{21}$ Esaias van de Velde I's Wooded Landscape with Armed Men Attacking a Wagon Party stands as an example of this genre. | fig. 7 | The image depicts a wagon barred from progressing along the country road by a group of armed men, who emerge from the cover of the forest on all sides. An attacker on the left of the composition has just fired his gun, which is aimed at one of the passengers in the covered wagon. The latter appears to be in the process of falling from the wagon as a result of a wound inflicted from the still smoking gun. To the right, five men carrying weapons charge out of the thick trees. In the background of this central scene, a lone figure runs away from the ambush. This man is presumably one of the drivers of the wagon, since his white horse stands abandoned at the front of the convoy. The scene takes place in a landscape framed on all sides with dense trees and shrubbery. With the exception of a dilapidated country house, just discernable behind the cover of trees on the right of the composition, there are no other buildings in view. This suggests that the attack is occurring well outside the city limits.

As this image attests, potential dangers awaited travellers as they went beyond city boundaries. Traditional representations of the countryside tended to present it as calm, safe, and peaceful. As Christopher Heuer has noted, Dutch art, and especially Dutch landscape art, tended to be positioned by critics as a "minute and happy transcribing of the visible world."22 Representations of landscapes that are not happy and benign thus deviate from this norm, and their production and circulation can reveal tensions about this projected 


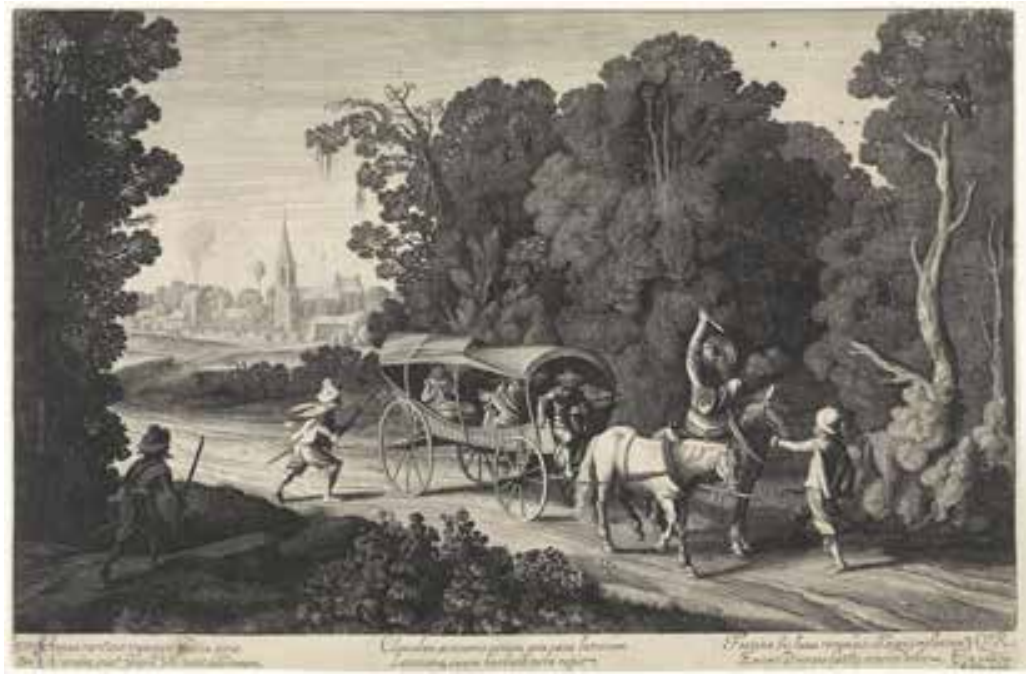

Figure 6. Jan Van de Velde II

after Esaias van de Velde, Ambush

of a Wagon, 1603-1641. Etching

and engraving, $28.0 \times 42.2 \mathrm{~cm}$.

Rijksmuseum, Amsterdam.

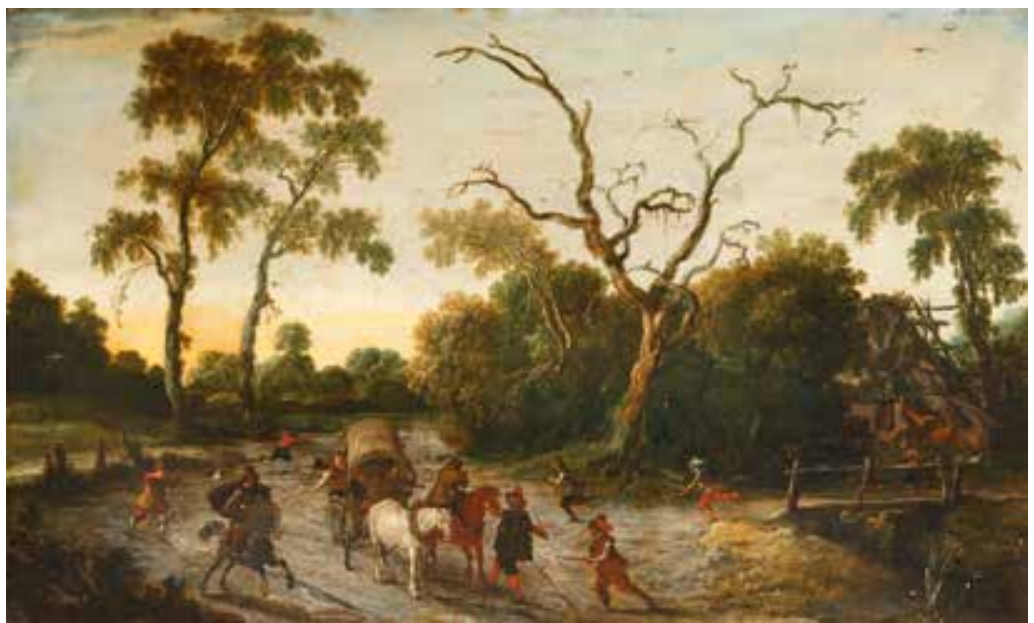

Figure 7. Esaias van de Velde I,

A Wooded Landscape with Armed Men

Attacking a Wagon Party, 1673.

Oil on canvas, $30.5 \times 52 \mathrm{~cm}$.

Image Courtesy of the Sackville

Collection/National Trust Images. 


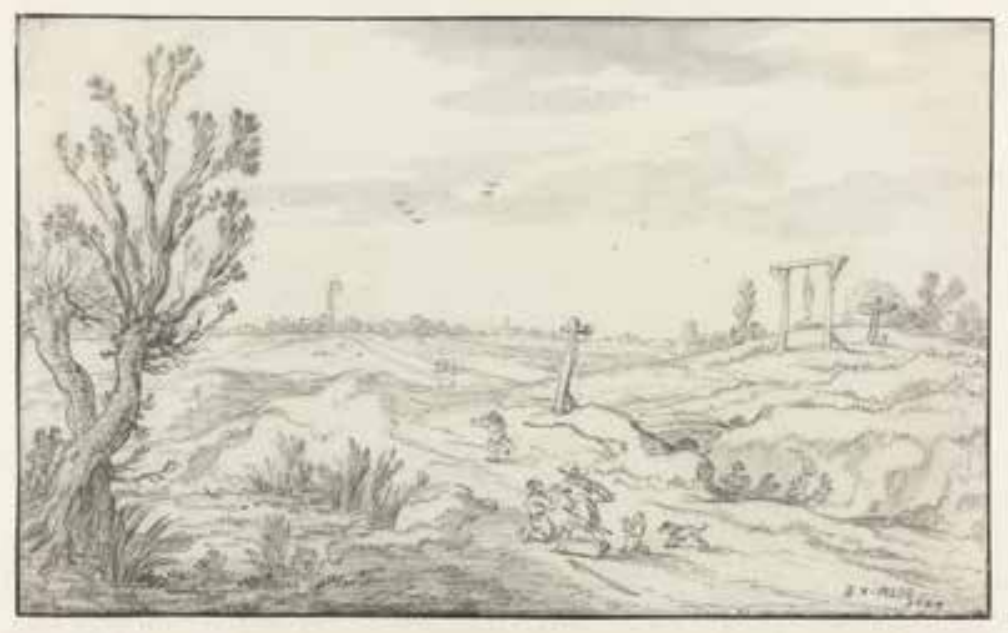

Figure 8. Esaias van de Velde,

Travelers Attacked by a Bandit,

1627. Drawing, $18.9 \times 30.6 \mathrm{~cm}$.

Rijksmuseum, Amsterdam.

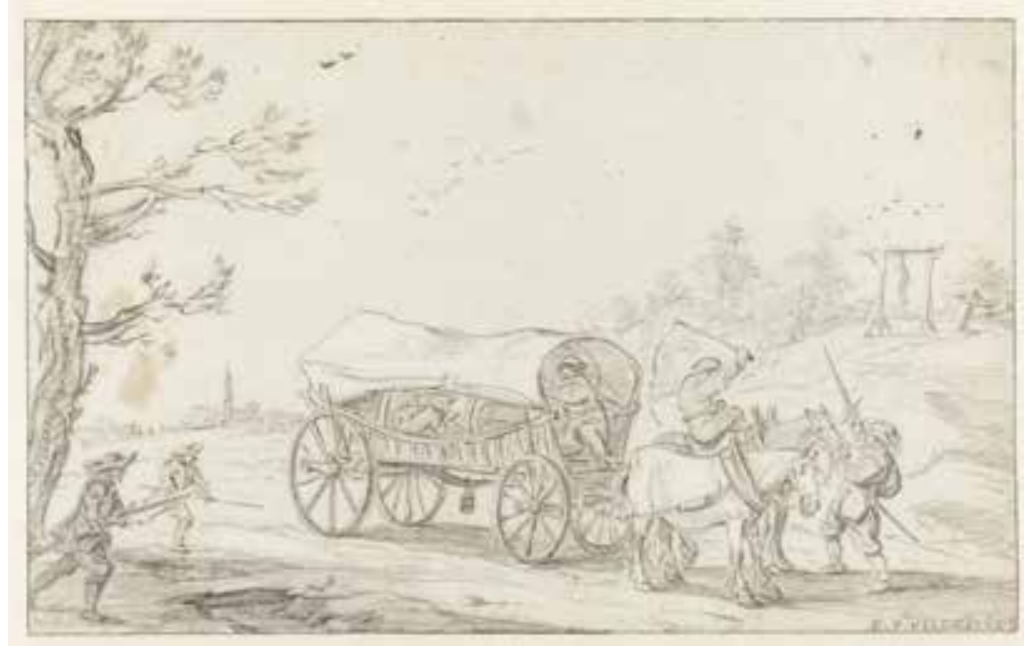

Figure 9. Esaias van de Velde,

Ambush of a Wagon, 1626. Drawing,

$19.8 \times 31.5 \mathrm{~cm}$. Rijksmuseum, Amsterdam. 
23. David Kunzle, From Criminal to Courtier: The Soldier in Netherlandish Art 1550-1672 (Leiden and Boston: Brill Academic Publishers, 2002), 317.

24. See J. M. Montias, "Works of Art in Seventeenth-Century Amsterdam: An Analysis of Subjects and Attributions," in Art in History, History in Art: Studies in Seventeenth-Century Dutch Culture, ed. David De Vries Jan Freedberg (Santa Monica, CA: The Getty Center for the History of Art, 1991), 331-71.

25. Folke Ström, On the Sacral Origin of the Germanic Death Penalties (Stockholm: Håkan Ohlsson, 1942), 160.

26. "om door de Lucht en Vogelen des Hemels verteerd te worden" (unpaginated confession book located in the collections of the Amsterdam Municipal Archives), inventory number 005061000004_001.

27. H. C. Jelgersma, Galgebergen En Galgevelden, 37. image of security. Artists were "ambushing expectations" of what would typically be pictured in images of the countryside. ${ }^{23}$ The fact that scenes of assault and banditry were produced in a variety of media suggests that the public-the primary consumers of these images-was preoccupied with matters concerning criminal behaviour and safety. The number and variation of surviving images depicting scenes of ambush and plunder is indicative of an active market demand for compositions that deviated from the calm and pastoral scenes that were also immensely popular during the period. ${ }^{24}$ These two, seemingly contradictory manners of representing the Dutch landscape reveal a tension between the projected image of safety and what the reality of the situation may have actually been.

The concern over security and the effectiveness of punishment rituals comes to the fore in images that position scenes of ambush against the gallows, which function in this instance as symbols of the law. Esaias van de Velde produced two drawings depicting assaults on travellers occurring in front of occupied gallows. The first, a drawing from 1627 , pictures three travellers being attacked by a bandit. | fig. 8| On the right of the composition, one sees a gibbet and wheel located on an elevated mound. The gibbet is occupied by a hanging corpse, which appears to survey the scene of assault taking place on the road below. The second drawing, Ambush of Wagon from 1626, | fig. $9 \mid$ shows a horse-drawn carriage that has been stopped by a bandit wielding a sword. Two other assailants run toward the wagon carrying weapons in their hands. In the background, loose lines suggest the outlines of the city this convoy has left. As the drama unfolds in the foreground of the image, a single body hanging on the gallows seems to bear witness to the illicit deeds. This striking juxtaposition of criminal activity and its potential repercussions seems to foreshadow a probable outcome for the scene depicted. The unexpected combination could also be seen as an overt manifestation of anxieties about the effectiveness of law. This drawing is just one of a number of extant compositions that feature bandits blatantly ambushing people and property within sight of the gallows. This suggests that the gallows failed as a potent means of preventing future crime by warning of consequences.

Looking more closely at these two images, the ambiguity of meaning associated with the gallows becomes evident in additional ways. A number of black birds circle above the decomposing bodies, |figs. 8, 9| referencing the obvious fact that birds of prey consume cadavers. Furthermore, the birds' consumption of the condemned corpse often formed part of official sentences. In one sentence, it was decreed that the felon "never be committed to the earth, that the wind will blow him apart and the crows, ravens and other birds will tear him up and consume him." ${ }^{25}$ Another, similar sentence stipulated that the executed criminal's body be placed on public view at the gallows field "to be consumed by the air and the birds of heaven." ${ }^{26}$ Seventeenth-century sentencing formulas reveal a preoccupation with the deviant body being consumed by birds. This is even underscored in the name of the gallows field in Amsterdam-the Volewijk-possibly derived from vogel wijk, which means the region of the birds. ${ }^{27}$

The link between the gallows and the birds' attraction to the exposed bodies was clearly evident to contemporaries, as bird catchers would often gather 
at this location to hunt and set out traps. Avercamp's Riverscape at Kampen includes a bird hunter among the multiple groups of people gathered. | fig. 1 | More strikingly, Jan van de Velde II's 1615 etching Landscape with Bird Catchers at their Nets visualizes how elaborate such activities around the gallows could become. | fig. 10| In it, a party of well-dressed men and women is huddled in the shade provided by a large tree at the corner of the print. A male member of this party holds the strings attached to the nets laid out on the ground just below the gallows. The fact that a decomposing body is still attached to a post at the gallows seems to offer no deterrent to this elaborately attired party. No one in the pictured group even glances at the dead body, which attracts the birds they have come to catch.

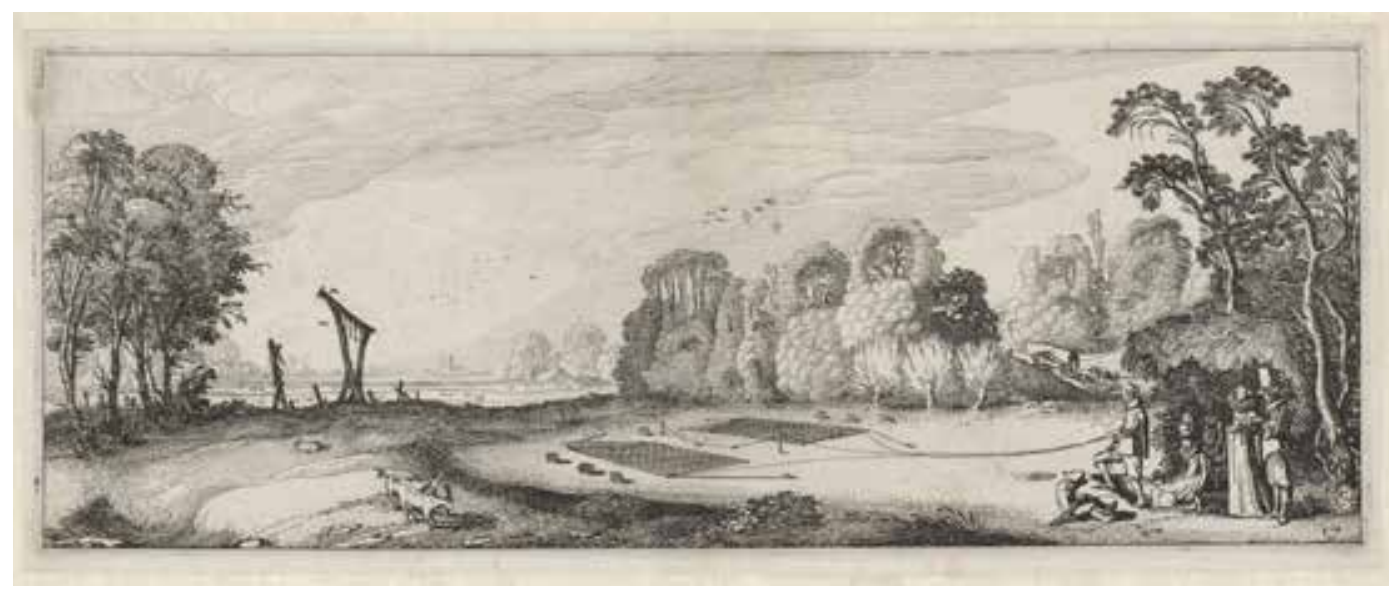

Figure 10. Jan van de Velde II, Landscape with Bird Catchers at their Nets, 1615 . Etching, $12.1 \times 31.8 \mathrm{~cm}$ Rijksmuseum, Amsterdam.
While sentencing formulas expressed a desire that the criminal's body "never be committed to the earth," in reality pieces of decomposing flesh would inevitably fall from the gibbet to the ground below. These human remains would, over time, serve as a source of nutrients for the grass and vegetation growing around the gallows. This grass would then become the food source for animals, like cows-another quintessential symbol of Dutch identity. In a number of images with gallows, cows and goats wander unhindered around the displayed bodies. $\mid$ fig. 1, 5, 10 | In Avercamp's Riverscape at Kampen, two plump cows lazily eat grass and drink the water around the gallows. | fig. 1 | Goats graze while curiously observing the bird catchers in Jan van de Velde's etching. | fig. 10| In Esaias van de Velde's painting of 1619, a centrally positioned cow is in the process of consuming grass at the foot of the gallows. | fig. 5| This cow is more prominent and represented with even greater detail than the human figures; its presence highlights the cycle of life and death, while also pointing to its role in enabling the deviant body to re-enter the purified limits of the city. The lone cow at the base of the gallows will soon re-join its companions on the other side of the fence, transgressing the established boundary between interior and exterior, polluted and purified. Furthermore, the material life of drawings, prints, and paintings that recorded the gallows also enabled this transgression and blurring of boundaries, 
as they would have been purchased by residents and taken into their homes within city limits to be displayed on walls, or included in print albums to be viewed, contemplated, and discussed with friends and family. This points to an interest in what occurred to bodies cast out beyond city borders, thus underscoring the prominence of visual culture in considerations of safety and the cycle of life and death more generally.

\section{Landscape's Limits}

Since the gallows were typically found just beyond city limits, this intermediate location allowed artists to represent, and thus work through, the implications of authorities' failings. As Elizabeth Honig has argued, the city's outer fringes-the banlieue, as she categorizes it-was a place with its own character, where behaviour that defied the expectations associated with regular city or country conduct could occur. For Honig, the banlieue was a critical space, as it became the location in which resolutions to social tensions "could be imagined and even tested without threatening the fundamental orders of place and society." ${ }^{28}$ Honig's characterisation of the banlieue recalls the work of Arnold Van Gennep on liminality, in which he also asserts the ambiguous and indeterminate attributes of this state. ${ }^{29}$ Situated in the banlieue, the gallows existed in a liminal position that enabled people from diverse social spheres to mix in ways not possible within the confines of the city. It permitted the slippage of defined categories through participation in leisure activities and entertainment that occurred, most peculiarly, near exposed criminal bodies.

Anthonie van Borssom's pen and ink drawing of the Amsterdam gallows field gives the impression of an ordered and sombre place meant to provoke quiet, internal reflection and contemplation. |fig. 2 | As already seen with the bird catchers, as well as those gathered along the river near Kampen, this internal reflection was not always the reaction the gallows elicited. $\mid$ fig. 1, 10 $\mid$ It also attracted the curious and those seeking entertainment and recreation. Families, groups of friends, and travellers would gather to enjoy the pleasures of the seasons with apparently little concern for, or alarm at, the exposed bodies that were in such close proximity to their leisure activities. The location of the gallows in the open space outside city limits facilitated the mixing of people from diverse social spheres in ways that were not possible within town. This again reinforces the connection between the gallows field and the banlieue, as

28. Elizabeth Alice Honig, "Country Folk and City Business: A Print Series by Jan Van De Velde," The Art Bulletin 78, 3 (1996): 511.

29. See Arnold Van Gennep, The Rites of Passage (Chicago: University of Chicago Press, 1960).

30. Elizabeth Alice Honig, "Country Folk and City Business, op. cit.: 511.

31. Mikhail Bakhtin, Rabelais and His World, trans. Helene Iswolsky (Bloomington and Indianapolis: Indiana University Press, 1984), 310.

32. Ger Luijten et al., eds. Dawn of the Golden Age: Northern Netherlandish Art, 1580-1620 (Amsterdam and New Haven, ст: Yale University Press, 1993), 635 . both permitted the slippage of defined categories through participation in leisure activities. ${ }^{30}$ Images of the gallows and its decomposing bodies also resonate with accounts of grotesque and comic spectacles in which, as Mikhail Bakhtin notes, "the limits between the body and the world are erased." 31

The pursuit of pleasure in the shadow of the gallows took place throughout the year, including in the middle of winter. Hendrick Avercamp's canvases commonly feature the pastimes of winter, another popular theme of seventeenth-century Dutch painting. Avercamp's Enjoying the Ice Near a Town | fig. 11 | shows a large group of people enjoying diverse leisure activities on a broad expanse of frozen water near a town. Enjoying the ice are a number of women, whose wealth is indicated by their ermine-lined cloaks and the fashionable masks worn to keep their faces warm. ${ }^{32}$ An analysis of the type of dress and activities of the various groups reveals that there are also 


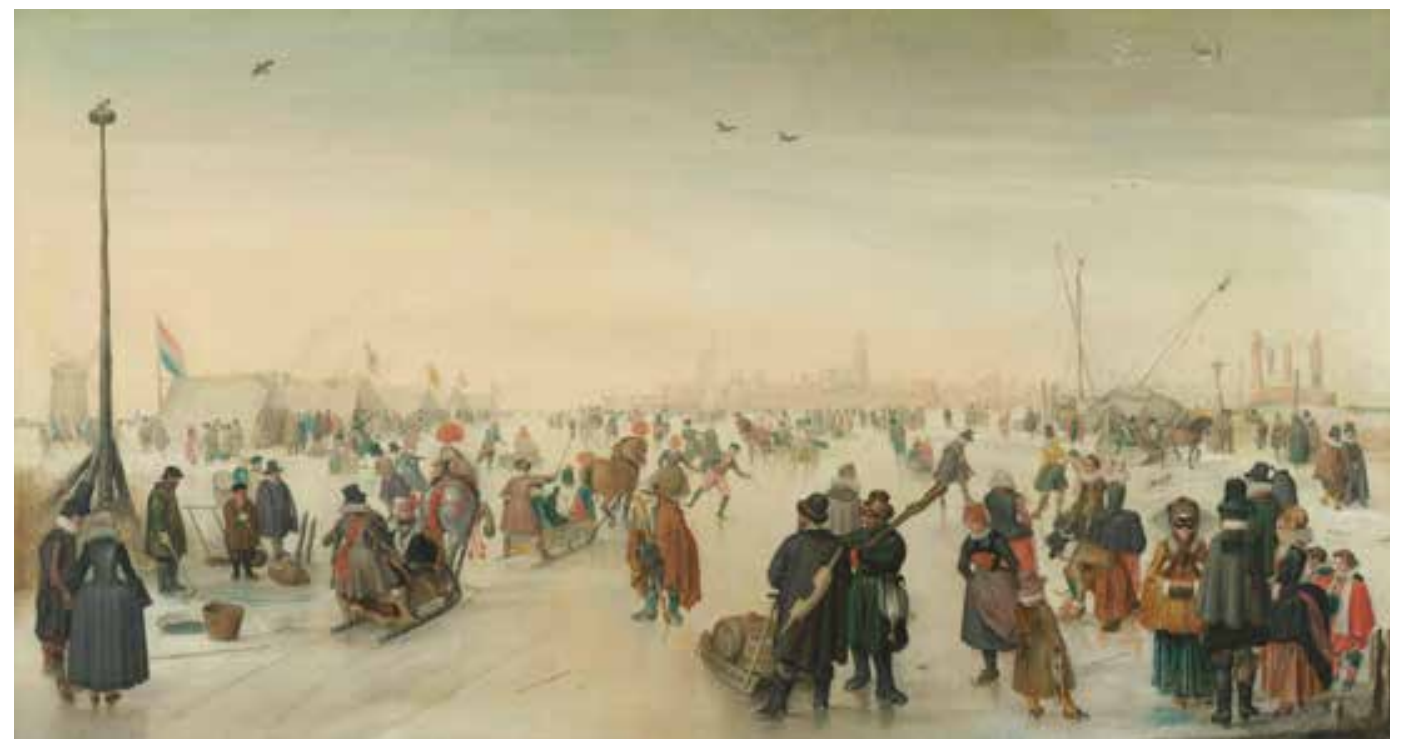

Figure 11. Hendrick Avercamp, Enjoying the Ice Near a Town, c. 1620. Oil on wood and textile, $47 \times 89 \mathrm{~cm}$. Rijksmuseum, Amsterdam; long-term loan from private collectors. burghers, peasants, beggars, and children on the ice. In essence, this winter scene brings people from all walks and stations of life together to socialize and seek entertainment. In the left, middle ground of the composition, one sees a row of tents set up to sell refreshments. Even horses are shown on the ice, as they were used to pull sleds transporting people and goods. Many of the figures depicted by Avercamp are engaged in activities such as ice fishing and playing kolf; he even included a group of gipsy women telling the fortunes of those gathered on the ice. What is of particular relevance in this image, however, is Avercamp's inclusion of a gallows on the right middle ground of the composition. Discretely located, yet still visible behind an overturned, partially submerged boat, the bodies of three felons are displayed. As seen in previous images, not one of the dozens of figures depicted in the composition appears to notice the suspended bodies. Unlike the drawing by van Borssom, |fig. 2 | the punished criminals do not inspire contemplation and internal reflection. Instead, Avercamp's image presents the area surrounding the gallows as one on the outskirts of the city in which people from different social classes and backgrounds mix in the pursuit of entertainment and leisure.

The freezing of canals and rivers during the winter would have disrupted daily activities, as waterways were, and still are, crucial to the transport of goods and people in the Netherlands. This change in daily routine would have inspired a festive atmosphere, and the activities taking place on the ice and in the vicinity of the gallows resemble those that would occur during a carnival or a fair. A commonly discussed aspect of early modern fairs is their ability to blur boundaries between varying social classes, thus providing an opportunity for established social hierarchies to be inverted. As Peter Stallybrass and Allon White have noted, fairs were agents of transformation that "promoted a conjecture of discourses and objects favourable to innovation." ${ }^{33}$ That Avercamp depicts these types of festive activities occurring beside the gallows suggests that such representations would have also generated discourse 
33. Peter White and Allon Stallybrass, The Politics and Poetics of Transgression (Ithaca, NY: Cornell University Press, 1986), 36.

34. This is in keeping with claims made by scholars such as Stuart Hall regarding the lack of constant or fixed meaning of representations. For Hall, meaning is dependent on context, allowing images to have shifting signification. See Stuart Hall ed., Representation, 1-74.

35. Bakhtin, Rabelais and His World, 21.

36. For an expanded discussion of scatological references in early modern European art and literature, see Jeff Persels and Russell Ganim, eds., Fecal Matters in Early Modern Literature and Art: Studies in Scatology (Aldershot, UK, and Burlington, vT: Ashgate Publishing Co., 2004).

37. Joseph Leo Koerner, Bosh and Bruegel: From Enemy Painting to Everday Life (Princeton: Princeton University Press, 2016), 363.

38. See Walter S. Gibson, Figures of Speech: Picturing Proverbs in Renaissance Netherlands (Berkeley: Univeristy of California Press, 2010), 6-17; and Natalie Zemon Davis, "Proverbial Wisdom and Popular Errors," in Society and Culture in Early Modern France (Stanford, CA: Stanford University Press, 1975), 227-67.

39. Stephanie Porras, "Resisting Allegory: Pieter Bruegel's 'Magpie on the Gallows,' 'Rebus 1 (2008): 8 .

40. See, for example, Pieter Bruegel the Elder's Netherlandish Proverbs (Topsy Turvey World), 1559, oil on oak panel, $117 \times 163 \mathrm{~cm}$, collection of the Staatliche Museum, Berlin. among viewers about the place of the grotesque, illicit body and the rituals that accompanied these public events. The festive atmosphere of the image would have prompted interrogation, discourse, and innovation, much like that experienced at the actual fair.

While Avercamp's representation highlights the pleasures of winter and the festive atmosphere it produced, closer inspection also reveals the hardships and realities of life. For the less-affluent and working classes, the winter held the possibility of suffering or death due to food shortage and cold. While many of the figures are engaged in leisure activities, there are others who are actively fishing or searching for eels. There are also beggars who seek alms from those gathered on the ice. The continued need for commerce and trade is also emphasized by the movement of goods and products across the ice. Read in conjunction with these overt signs of the difficulties of daily life, the signification of the gallows takes on new meaning. ${ }^{34}$ As an overt sign of death, their presence indicates that, despite the disparate circumstances of all the people depicted, not everyone would survive the winter. The potential for death looms over the lives of all and, much like the common vanitas compositions of Dutch paintings, reminds viewers of the transience of life and earthly pleasures.

The inclusion of the gallows in images that feature entertainment can be further read as a warning and a call for caution and balance, as evidenced by a detail included in Enjoying the Ice Near a Town. | fig. 11 | The grotesque, criminal body that will eventually decompose upon the gallows can be linked to the concept of degradation, which is associated with the lower stratum of the body, including the act of defecation. This process of degradation can be both destructive and regenerative. According to Bakhtin, "To degrade an object does not imply merely hurling it into the void of nonexistence, into absolute destruction, but to hurl it down to the reproductive lower stratum, the zone in which conception and new birth take place." ${ }^{35}$ In the case of Avercamp's composition, a visualization of this concept of degradation associated with the grotesque can be discerned through the inclusion of a man defecating at the foot of the gallows. ${ }^{36}$ | figs. 11, 12 | Considered within the context of popular Netherlandish proverbs and sayings, this detail takes on further significance, since to defecate at the foot of the gallows meant to be unconcerned with the outcome of one's irreverent and potentially subversive actions against authority. ${ }^{37}$

The use of proverbs, such as the one featured in Avercamp's image, was part of far-reaching oral, written, and visual traditions in the Netherlands. ${ }^{38} \mathrm{As}$ Stephanie Porras has argued, "Proverbs encouraged the production of meaning through the performance of interpretation, discussion and debate." ${ }^{9} 9$ Proverbs were thus continually expanded and revised, which suggests that their meanings transformed over time. Large-scale paintings, like Pieter Bruegel the Elder's Netherlandish Proverbs (1559), visually illustrated popular sayings and even included the figure of a man defecating at the gallows. ${ }^{40}$ These oral, textual, and visual precedents suggest that viewers of Avercamp's composition would have understood the meaning of this figure. Similar to textual anthologies of proverbs, these images also prompted dialogue, not only about the meaning of a given adage, but also about its implications for contemporary 


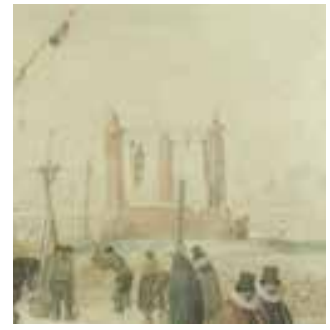

Figure 12. Hendrick Avercamp, Enjoying the Ice Near a Town (detail) c. 1620. Oil on wood and textile, $47 \times 89 \mathrm{~cm}$. Rijksmuseum, Amsterdam; long-term loan from private collectors.

41. For a more detailed discussion on humour and visual culture in the Dutch Republic, see the catalogue accompanying the recent exhibition at the Frans Hals Museum. Anna Tummers, et al., The Art of Laughter: Humour in Dutch Paintings of the Golden Age, exh. cat. (Zwolle and Haarlem: Frans Hals Museum, 2017).

42. This subversion at the gallows supports Michel Foucault's argument regarding the movement of penal systems away from public executions and torture as a means of preventing unintended reactions from those gathered to witness the event. See Michel Foucault, Discipline and Punish: The Birth of the Prison, trans. Alan Sheridan (New York: Vintage Books, 1977).

43. Ann Jensen Adams, "Competing Communities in the "Great Bog of Europe': Identity and Seventeenth-Century Dutch Landscape Painting," in Landscape and Power, ed. W.J.T. Mitchell (Chicago: Univeristy of Chicago Press, 1994), 65. social issues. This was especially so in images that explored proverbial sayings through a comedic lens. ${ }^{41}$ The humorous detail of the defecating figure below the scaffold would have thus elicited responses similar to those occasioned by the images of ambush occurring in the vicinity of the gallows. Seen in the context of seventeenth-century attempts to impose order and impart authority within the confines of the city, this detail in Avercamp's composition could also have provoked considerations of the ineffectiveness and limits of the law. This painting was one of many visual images that drew attention to the boundaries of the city, the movement of bodies, and the cycle of life and death more generally. The site of the gallows field and its representation in visual culture could thus be imbued with references that subverted what the physical structure of the scaffold and the criminal bodies placed on it were intended to signify. ${ }^{42}$ In the case of Avercamp's winter scene, this subversion occurred within an atmosphere of humour and comedy embedded in the festive culture of the liminal space that the gallows could also become.

\section{Conclusion}

The "awesome ceremonies" (ontsaggelijke plegtigheeden) accompanying criminal punishments, including the added stipulation that certain executed bodies be placed on display at the gallows field, was intended to project the impression that deviant actions and unlawful behaviour would not be tolerated by officials. The location of the gallows at significant boundaries and visible entrances to major cities was an important means of asserting authority and control. Representations of the Dutch landscape were central to the formulation of a cohesive, communal cultural identity, and so the image of the gallows within the landscape took on added social significance. Unlike other European countries, where monarchs served to symbolize national identity, the Dutch Republic turned to the land to signify the nation. According to Ann Adams, the land provided a ready and unclaimed site for the negotiation of potentially fragmenting issues. ${ }^{43}$ In a society comprised of people with different origins, and from varying economic, political, and religious backgrounds, representations of the Dutch landscape offered a space where communal identities could emerge and flourish. This was achieved while civic authorities overlooked, surveyed, and managed behaviour to ensure the continuation of a safe and peaceful city. By casting out the illicit body, and stipulating that its physical remains not pollute the land, civic officials were declaring their control over deviance as well as the purity and security of the nation.

The sight of the decomposing criminal body denied a proper burial was intended to trigger inner reflection concerning the impact of immoral actions on the overall wellbeing of the social body. While images and elaborately staged processions to the gallows were intended as warnings against actions that harmed the peaceful and ordered workings of the city and its residents, the circulation of certain types of images would have elicited a contradictory interpretation from some viewers, thus taking on ambiguous and potentially subversive meanings. In the case of scenes that coupled the imagery of ambush or robbery with that of the gallows, the juxtaposition of these two events drew attention to the inevitability of death. These images also point toward the ineffectiveness of law enforcement and judicial authorities when 
it came to truly protecting residents and travellers from attack. The fact that an active market existed for representations that depicted illegal acts taking place within sight of punished criminals on the gallows suggests that such forms of visual culture provoked dialogue among viewers about the ability of authorities to ensure their continual safety and maintain order in the places they were charged with overseeing. The production of these types of representations underscores the role of images in bringing to the forefront anxieties associated with personal safety and the cycle of life.

Diverse people would also gather near the gallows field to engage in pleasurable leisure activities, such as skating, fishing, hunting, and picnicking. The close proximity of this jovial atmosphere to the gallows confers upon this site a status similar to the banlieue, where the disruption of established social order occurred through the mixing of people in pursuit of pleasure in the shadow of death. The visual representation of the proverbial man who defecates at the foot of the gallows invited viewers to reflect on the efficacy of authorities in ensuring their safety and the deterrent that the prospect of death held to transforming behaviour. Imagery of the gallows thus carried a multiplicity of meanings. Depending on the location of the image, its mobility and circulation, as well as the activities it represented taking place in the shadow of outcast bodies, it could signify varying degrees of order and control. Authorities could not, therefore, fix all of the meanings associated with the gallows field. The proliferation of this subject, as well as its circulation in diverse genres of visual culture, underscores the role of representations of the criminal body in activating discourses that went against the officially sanctioned message of civic power, thus underscoring the limits of control realized in punishment rituals. q 